\title{
THE PRESTIGE AND DECLINE OF THE OFFICIAL (STATE) LANGUAGE IN THE GRAND DUCHY OF LITHUANIA (FIFTEENTH-SIXTEENTH CENTURY): PROBLEMS IN BELARUSIAN HISTORIOGRAPHY
}

\author{
Artūras Dubonis
}

ABSTRACT The status of the Ruthenian language and use of Lithuanian in public life in the Grand Duchy of Lithuania (henceforth GDL) remains one of the most hotly debated topics in Lithuanian historiography. In this article, the use of Ruthenian (early Belarusian) is analysed as the official ('state') language of the GDL, as it is presented in the latest works by Belarusian and Polish researchers and Lithuanian language studies researchers. This analysis looks at the problems that arise when examining the flexible and extraordinarily dynamic use and interrelation of languages in the GDL in the 15th-16th centuries, which changed every few decades and was based more on customs and traditions than laws.

The prevailing opinion in Belarusian historiography today points to the dominance of Ruthenian (the early Belarusian language) in the GDL in the 14 th-17th centuries. ${ }^{1}$ It is seconded by the latest Polish research on Lithuanian language studies. ${ }^{2}$ Uladzimir Sviazhynsky is one of the most ardent supporters of the Belarusian

${ }^{1}$ А. Журавский, 'О канцелярском языке Великого Княжества Литовского', Lietuvos istorijos metraštis. 1983 metai (Vilnius, 1984), pp. 28-29; Вялікае Княства Літоўскае. Эниыклапедыл у двух тамах, т. 1: $A-K$, рэдкал.: Г.П. Пашкоў (гл. рэд.) і інш. (Мінск, 2005), рp. 60-61, 300-301, 303; Гісторыя Беларусі, т. 2: Ю. Бохан, Г. Галенчанка і інш. Беларусь у перыяд Вялікага Княства Літоўскага (Мінск, 2008), p. 568. In public life, ethnic Lithuanians used Ruthenian as the official language for record-keeping. See: О. Дзярнович, 'Литовский язык в мультикультурном обществе Великого княжества Литовского XV-XVII веков', Исторический путь литовской письменности. Сборник материалов конференции, науч. ред. С.Ю. Темчин (Вильнюс, 2005), р. 20.

2 There is agreement that Ruthenian was widely used in ethnic Lithuania in the 16th century; Lithuanian lost its function as a language for public use, though it prevailed in the homes of peasants, some burghers and nobles for a long time still. See: G. Błaszczyk, Litwa na przełomie średniowiecza i nowożytności 1492-1569 (Poznań, 2002), pp. 302-303, 305, 307. Lithuanian was not a state (official) language. See: A. Zakrzewski, Wielkie Księstwo Litewskie (XVI-XVIII w.). Prawo - UstrójSpoleczeństwo (Warszawa, 2013), p. 255. 
position, defending it in discussions with Lithuanian and Ukrainian scholars. ${ }^{3}$ He underlines the official status of the state (early) Belarusian language and its prestige: this was the language the most important state laws, documents and records were written in, even being used to write Jewish and Tatar religious texts. He rests on the arguments of the Lithuanian researchers Levas Vladimirovas and Stanislovas Lazutka to illustrate the scarce use of Lithuanian, not as the home-spoken language, but in ethnic Lithuania generally. ${ }^{4}$ Aleh Dziarnovič echoes these scholars, adding that the use of Lithuanian in public life was limited, due to the generally unfavourable socio-linguistic and political situation. This limited use is illustrated in data from various spheres of

3 У. Свяжынскі, 'Праблема ідэтыфікацыі афіцыйнай мовы Вялікага Княства Літоўскага', Metriciana. Даследаванні і матэрыяль Метрыкі Вялікага Княства Літоўскага, т. 1 (Мінск, 2001), pp. 113, 124-125. For a review of this publication, see L. Karalius in a Belarusian periodical dedicated to research on the books of the Lithuanian Metrica, Lietuvos Metrikos naujienos, No. 5-2001 (Vilnius, 2002), pp. 18-21. For a discussion with Lithuanians, see А. Дубоніс, 'Да праблемы дзяржаўнай мовы ў Вялікім Княстве Літоўскім’, Metriciana. Даследаванні i матэрыялы Метрыкі Вялікага Княства Літоўскага, т. 3 (Мінск, 2004), pp. 203-219; У. Свяжынскі, 'Вяртаючыся да дыскусіі пра афіцыйную мову Вялікага Княства Літоўскага', ibid., p. 223. For a discussion with Ukrainians, see: В. Мойсієнко, ‘До проблеми виділення „західноруського“ наріччя, або якою мовою писали на теренах українсько-білоруського пограниччя у столітті', Українські гуманітарний огляд, вип. 7 (Київ, 2002), pp. 92-115, and У. Свяжынскі, 'Аб статусе беларускай і ўкраінскай моў у часы Вялікага Княства Літоўскага', Metriciana. Даследаванні і матэрыяль Метрыкі Вялікага Княства Літоўскага, т. 2 (Мінск, 2003), рр. 132-163.

4 У. Свяжынскі, 'Праблема ідэтыфікацыі афіцыйнай мовы', pp. 115-118. Vladimirovas claimed that everyone understood and used the early Belarusian language in ethnic Lithuania: 'Keeping in mind that this language was the official language of state administration and court organs, it was used, and thus understood, even in the northwest regions of the GDL, inhabited by Lithuanians and Samogitians' see: L. Vladimirovas, 'Kokia kalba buvo kalbama ir rašoma Lietuvos Didžiojoje Kunigaikštystėje XIV-XVII amžiais?', Lietuvos TSR aukštujų mokyklu mokslo darbai. Istorija, t. 22 (1982), p. 117. Lazutka gave specific data on the scale of the early Belarusian language's entrenchment in Lithuania: '... the lords, boyars, burghers and even some peasants' all knew the early Belarusian language, as it was not just the official language of the chancery of the Lithuanian state '.. but the language for social communication in general'. See: Lietuvos Metrika (1528-1547). 6-oji Teismy bylu knyga, eds. S. Lazutka, I. Valikonyte, et al. (Vilnius, 1995), pp. cxxi-cxxii; S. Lazutka, 'Język Statutów litewskich i Metryki litewskiej', Lithuania, 1997, No. 1-2, s. 32-33; later, the peasantry was removed from the group who knew the early Belarusian language. See: С. Лазутка, И. Валиконите, Э. Гудавичюс, Первый Литовский Статут (1529 г.) (Vilnius, 2004), pp. 64-68. 
social life in the 15 th-16th centuries. ${ }^{5}$ Because he 'overlooks' those facts that contradict his concept, the functionality of Lithuanian in the GDL does indeed appear forlorn: from the first half of the 15th century, it could not be understood by any neighbouring peoples, and was cast as a secret language (крыптамова). ${ }^{6}$ Sometimes he even poses the question whether the Lithuanian language mentioned in 15th-16th-century sources is at all related to contemporary Lithuanian. He notices that primarily Baltic dialects were used in the territory of ethnic Lithuania at that time. ${ }^{7}$ Only during the demise of the GDL does he attribute the Lithuanian language to Lithuanians: 'Essentially, the linguistic nomenclature of the 18th century clearly attributed the term "Lithuanian language" precisely to that Baltic dialect that is today known as the Lithuanian language.' 8

The image of the decline in use of Lithuanian painted by this author is an important factor in his socio-linguistic concept. Dziarnovič views linguistic relations in the multiethnic and multicultural society of the GDL as 'many diglossias' (мноства дыгласіяу), where each language in the territory of the GDL had its own traditional social functions. This phenomenon forced the speaker to assess (chose) his idioms on the socio-cultural scale of opposites: high-low, festive-everyday. Two different languages would not be used in the same social sphere. This explains why ethnic Lithuanians - the lesser nobles and merchants - could speak Lithuanian in everyday life situations in the 16th century, yet would revert to the official written Ruthenian (early Belarusian) language in the social sphere. ${ }^{9}$ Dziarnovič set out the spheres (levels) of use of Lithuanian in two tables. Here the situation from the first and second half of the 16th

${ }^{5}$ А. Дзярновіч, 'Літоўская мова ў Вялікім Княстве Літоўскім: паміж функцыяй і статусам’, Палітычная сфера, № 16-17(1-2) (2011), р. 120.

${ }^{6}$ Ibid., p. 116.

${ }^{7}$ In 1440, the Lithuanian elite was concerned that the ruler would understand his Baltic dialect-speaking subjects, and after some deliberation, it was decided that their language was Lithuanian. See: ibid., p. 117. The lesser nobility had preserved the means of communicating with their peasants in those territories where Baltic dialects were still in use, see ibid., p. 139. Direct ethnic links between contemporary Lithuania and the Litva of the GDL are usually dismissed in Belarusian historiography, which is why for them Litva can become the ethnically unidentifiable or Baltic dialectspeaking early inhabitants of Belarus. See: A. Dziarnovič, 'In Search of Homeland: Litva/Lithuania and Rus/Ruthenia in the Contemporary Belarusian Historiography', Belarusian Political Science Review. International Journal of Political Studies, vol. 3: 2014-2015 (Kaunas, 2015), pp. 90-115.

\footnotetext{
${ }^{8}$ А. Дзярновіч, 'Літоўская мова', р. 130.

${ }^{9}$ Ibid., p. 138.
} 
century is described in terms of a social environment extending beyond just the cited milieu of the lesser nobility and merchants. ${ }^{10}$ He distinguished four spheres: the private family, economic relations and record-keeping, official public communication (state and court chanceries), and religion. The tables show that in the diglossia of languages of the GDL, Lithuanian maintained a higher position amid the middle and lesser nobility, merchants and burghers of Vilnius, Kaunas and Trakai, in the homes of the peasantry and in the religious sphere (but without the middle nobility in the religious sphere). Even Lithuanian peasants, when communicating with economic and administrative subjects, had to know Ruthenian in order to make use of the opportunities offered by the 'higher-class, celebratory' language. An even stricter situation existed in state and court chanceries: peasants could only be understood if they used the early Belarusian language. ${ }^{11}$ Dziarnovič points to the existence of a dynamism in the language used by ethnic Lithuanians, especially the nobility, in certain spheres based on the high-low criterion: first of all, early Belarusian was used, and from the mid-16th century, Polish. He calls this the Slavonification of Lithuanians that was interrupted by the publication of Lithuanian books in Prussia and the GDL. ${ }^{12}$ No longer being able to speak in the Baltic dialects, the bilingualism of Lithuanians, ${ }^{13}$ and ultimately, their Slavonification in the 16th century (initially Belarusianisation, followed by Polonisation), ${ }^{14}$ forced ethnic Lithuanians to use the high, official and prestigious language of the GDL, early Belarusian. Dziarnovič in effect entrenched the claims of Grzegorz Błaszczyk and Sviazhynski about the prestigious status of Ruthenian (early Belarusian) in the GDL, its very broad base of users, and widespread use in ethnic Lithuania using socio-linguistic theory arguments. He is the only one to think that when undergoing Slavonification, Lithuanians both ceased using and learning their language. Neither Sviazhynski ${ }^{15}$ nor Błaszczyk ${ }^{16}$ made such claims.

${ }^{10}$ Ibid., pp. 134, 136.

${ }^{11}$ Ibid., pp. 134 and 136 (based on tables No. 3 and 4).

12 Ibid., pp. 135, 139.

13. The accentuation of the bilingualism of all ethnic Lithuanians, except the lords. See: ibid., p. 123.

${ }^{14}$ Ibid., p. 139.

15 У. Свяжынскі, 'Вяртаючыся да дыскусіі', р. 223.

${ }^{16}$ G. Błaszczyk, Litwa na przełomie, p. 305. 
Dziarnovič does not consider the research methodology he used as ideal, and seeks to improve it. But even as it is, it does allow seeing linguistic relations as a competition pyramid of cultural models of the GDL nations and estates: Ruthenian, and later, Polish, occupied their immovable positions at the top. Linguistic relations and their use in the GDL demand further discussion. Belarusian researchers, despite providing only a theoretical basis for their arguments, are looking at the same problems: 1) the official (state) language (or languages) and the question of its prestige, i.e. linguistic relations between Lithuanian, Ruthenian and Polish in public (official) life; 2) the Russification and Polonisation of Lithuanians; and 3) the self-awareness of nationality and estate among Lithuanians and Ruthenians. In this article, we direct all our attention to the first problem, while the other two should be discussed elsewhere.

By using the method Dziarnovič proposes, in terms of prestige or a lack thereof, we shall chronologically assess well-known and lesser-known data about the situation of the Lithuanian language in the GDL. The baptism of the Lithuanians in 1387, the granting of Christian Catholic rights and freedoms to the nobility by the Church, gave the newly-baptised nation of Jogaila, the King of Poland and Grand Duke of Lithuania, a social, political and confessional advantage in the state (especially compared to the Orthodox Ruthenians). ${ }^{17}$ According to Jan Długosz, Jogaila personally participated in the pastoral enlightenment of Lithuanians: he explained matters of faith in Lithuanian in Lithuania and Žemaitija: ${ }^{18}$ Lithuanian, as the nation's language, was transformed into a prestigious tool for learning about the Holy Truths, and was used by the king himself. By extension, the same prestigious, secular, publicly used Lithuanian language had to become established in the Lithuanian grand

${ }^{17}$ A. Dubonis, 'Lietuvių kalba Lietuvos Didžiojoje Kunigaikštysteje XIV a. pabaigoje ir iki pirmosios knygos (1547 m.): vartojimo politika ar politinis vartojimas?', Lietuvos Didžiosios Kunigaikštystès istorijos kraštovaizdis. Moksliniu straipsniu rinkinys, skiriamas profesorès Jūratès Kiaupienès 65-čiui, ed. R. Šmigelskytè-Stukienè (Vilnius, 2012), pp. 41-43.

${ }^{18}$ Ioannis Dlugosii Annales seu Cronicae incliti Regni Poloniae, lib. 10 (1370-1405) (Varsaviae, 1985), p. 160; Ioannis Dlugosii Annales seu Cronicae incliti Regni Poloniae, lib. 11 (1413-1430) (Varsaviae, 2000), pp. 23-24; Fijałek proves there having been regular religious education upon Jogaila's arrival in Lithuania, see: J. Fijałek, 'Uchrześcijanienie Litwy przez Polskę i zachowanie w niej języka ludu', Polska i Litwa w dziejowym stosunku (Warszawa etc., 1914), p. 62; A. Dubonis, 'Lietuvių kalba', p. 43. 
duke's court as well. Jan Długosz's facts about how the Grand Duke Casimir learnt Lithuanian in Vilnius in $1440,{ }^{19}$ and the treaty of 1446, where the Polish szlachta's envoys visited Casimir, now elected king of Poland, which foresaw Lithuanian-speaking courtiers as mandatory in the royal court, alongside the Polish courtiers, ${ }^{20}$ have become routine examples. In 1440, the Lithuanian language found itself in the position of the official state language, its status as such being confirmed again in 1446. But we should keep in mind its restricted use in its spoken form, then considered more important than its written variant, and its limited acceptance as a 'state language' only for use in official speeches made by the ruler at his court. Over the course of several decades, from the second half of the 15th century, the ever-stronger establishment of Polish in the court of the King of Poland and Grand Duke of Lithuania in Lithuania saw it assume the position of a prestigious official language, increasingly used by the Lithuanian nobility in public life. The obvious domination of Polish in the court of Lithuanian Grand Duke (and King of Poland) Casimir in Vilnius was visible already in 1492 in the examination of complaints brought forward by the West Prussian estates and Danzig legation over trade restrictions and other damages. The ruler and his Council of Lords, the Vilnius bishop and palatines discussed these matters firstly in Polish, then Lithuanian, and finally in Ruthenian. ${ }^{21}$ The widespread use of writing the Polish form of Lithuanian names for individuals and places in Latin entries in accounts books for Lithuanian Grand Duke Alexander's court demonstrates the significance of the Polish

${ }^{19}$ Ioannis Dlugosii Annales seu Cronicae incliti Regni Poloniae, lib. 11 et 12 (1431-1444) (Varsaviae, 2001), p. 256: '[...] veriti, ne nativo affectu plus esset Polonis quam Lithuanis affectus, officiales Lithuanos adiungunt et ipsum linguam et mores suos instruunt'.

${ }^{20}$ One of the Polish the szliachta obligations to the future King Casimir, dated 19 September 1446: '[...] familiares linguagii cuiuscunque tenere, habere et fovere [...]', see Akta unji Polski z Litwa 1385-1791, wyd. S. Kutrzeba i W. Semkowicz (Kraków, 1932), No. 69, p. 117. J. Matusas, 'Nuo kada Lietuvoje kalbama lietuviškai', Mūsu Vilnius. No. 16(210) (1936), p. 253; A. Dubonis, 'Lietuvių kalba', p. 46; R. Ragauskienė, 'Kalbinè padètis Lietuvos Didžiojoje Kunigaikštysteje (iki XVI a. vid.): interpretacijos istoriografijoje', Lituanistica, No. 3(93) (2013), p. 147.

${ }^{21}$ Hansisches Urkundenbuch, Bd. 11, ed. v. W. Stein (München u. Leipzig, 1916), pp. 363-364: '[...] Daruff wart handelt gehalt itzundt Polnisch, itzund Lithows, itzundt Reuszch [...]'. Comments by K. Jablonskis, Lietuviu kultūra ir jos veikejai, ed. V. Merkys (Vilnius, 1973), p. 37. 
language in the ruler's court in Vilnius. ${ }^{22}$ On the other hand, it was nevertheless just one of several languages used here, as a group of Ruthenian scribes and dyaki (clerks) ${ }^{23}$ worked in the ruler's chancery. The name of the scribe Ivanas Sapiega is also very telling, though these scribes were headed by the Vilnius palatine, Chancellor Mikalojus Radvila, a Lithuanian. Mikalojus Radvila was one of the participants in the Council of Lords that in 1492 discussed Prussian envoys' complaints over trade infringements in three languages. In the Polish court of King Alexander, we also come across some Lithuanians: three Lithuanian priests served as chaplains in the king's chapel, who had to meet the religious needs of the king and his milieu. ${ }^{24}$ Likewise, others were found in his Lithuanian court. ${ }^{25}$ Despite becoming increasingly prestigious in Alexander's court in Vilnius, it need not have become so in the GDL under his reign. In the oft-cited speech by the ruler's secretary, the Vilnius Cathedral priest and diplomat Erazm Ciołek, of 31 March 1501, to the Pope in Rome, where he passes on the opinion of the ruler of the GDL and the Council of Lords, ${ }^{26}$ he explains: there are two nations and two languages in the state, Lithuanian and Ruthenian; Lithuanians preserve their language, and ensure that Linguam propriam observant, but they use Ruthenian, as it is easier and simpler to use, as it is spoken by almost half the state. ${ }^{27}$ Polish, the language of the ruler's court, had basically 'dropped out' of the picture.

Thus, Dziarnovič's conclusion that in the first half of the 15th century Lithuanian was merely a secret language that was incomprehensible to others is misleading.

Ruthenian is not convincingly prestigious. Its use up until the end of the 15th century applied to the rather scant documentation

${ }^{22}$ Lietuvos didžiojo kunigaikščio Aleksandro Jogailaičio dvaro sq̨skaitu knygos (1494-1504), eds. D. Antanavičius, R. Petrauskas (Vilnius, 2007).

${ }^{23}$ K. Pietkiwicz, Wielkie Księstwo Litewskie pod rządami Aleksandra Jagiellończyka (Poznań, 1995), pp. 16-20.

${ }^{24}$ J. Skibniewska, Dwór królewski Aleksandra Jagiellończyka w latach 1501-1506 (Lublin, 2015), pp. 63, 313-315 (No. 1, 6, 14 in the list of courtiers).

${ }^{25}$ K. Pietkiwicz, 'Dwór litewski wielkiego księcia Aleksandra Jagiellończyka (1492-1506)', Lietuvos valstybé XII-XVIII a., sud. Z. Kiaupa, A. Mickevičius, J. Sarcevičienè (Vilnius, 1997), pp. 88-89.

${ }^{26}$ A. Dubonis, 'Lietuvių kalba', p. 53.

${ }^{27}$ Oratio Erasmi Vitellii ... ad Alexandrum VI, pontificem maximum ..., Vetera monumenta Poloniae et Lithuaniae gentiumque finitimarum historiam illustrantia, ... ab A. Theiner, t. 2 (1410-1572) (Roma, 1861), p. 278. 
of the GDL's administrative, judicial and other functions. ${ }^{28}$ As such, the official Ruthenian record-keeping says little about linguistic relations in the state, and cannot be an argument to promote the high status of the Ruthenian language. The scale of its public spoken use is also unclear, but we do know that it was used alongside Lithuanian and Polish in the Lithuanian grand duke's court. ${ }^{29}$ The Lithuanian and Polish nobility of the 15 th century did not really discuss the question of its use in their mutual political relations. All state privileges were written in Latin, the prestigious official written language. ${ }^{30}$ The entrenchment of Ruthenian in the ruler's chancery and in the routine ruling of the land was not legally sanctioned, as was the case with Lithuanian in Casimir's court; however, an indirect ideological explanation was given. In the legend of the Lithuanians' origins created during Casimir's reign, Ruthenians, i.e. pycb, were placed lower in the Lithuanian state social hierarchy: ${ }^{31}$ Ruthenians were a conquered and incorporated nation, whose language and writing the Lithuanians, descendants of the Romans, had learnt, like Rimantas, the son of Traidenis (who ruled in the second half of the 13th century). His father sent him to Lev, the Prince of Vladimir, to learn the Ruthenian language and writing, and later Rimantas converted to Orthodoxy. ${ }^{32}$ These Orthodox Lithuanians-Ruthenians participated legitimately in the rule and development of the state.

${ }^{28}$ М. Мозер, ‘Что такое „простая мова?', Studia slavica Academiae scientiarum hungaricae, t. 47(3-4) (2002), pp. 223, 228-230.

${ }^{29}$ Evidence of this is the request from the Teutonic Order's grand marshal dated 14 June 1446 to the grand master that he present his servant Jokuša as translator for the meeting with the Lithuanians by the River Šventoji, as his chamber servant Jokūbas from Kaimè had insufficient knowledge of Ruthenian. See Regesta historico-diplomatica Ordinis S. Mariae Theutonicorum 1198-1525, pars 1: Regesten zur Ordensbriefarchiv, vol. 1: 1198-1454, Zweiter Halbband (1433-1454), Hrsg. E. Joachim, W. Hubatsch (Göttingen, 1948), p. 590 (No. 9107). It was often the case that the use of such less-spoken languages in negotiations 'hid' the content of any off-the-record conversations. See: A. Szweda, Organizacja $i$ technika dyplomacji polskiej $w$ stosunkach z Zakonem Krzyżackim $w$ Prusach $w$ latach 1386-1454 (Torun, 2009), pp. 175-176.

${ }^{30}$ A. Zakrzewski, Wielkie Księstwo Litewskie, pp. 256-257.

${ }^{31}$ For more on the citation of literature, see A. Dubonis, 'Lietuvių kalba', pp. $48-49,52$.

${ }^{32} \mathrm{M}$. Stryjkowski, O początkach, wywodach, dzielnościach, sprawach rycerskich i domowych stawnego narodu litewskiego, żemojdzkiego i ruskiego ..., ed. J. Radziszewska (Warszawa, 1978), p. 215; Bychowiecz Chronicle, Полное собрание русских летописей, t. 17 (Масква, 2008), col. 488. 
They were also viewed favourably by Maciej Stryjkowski (1547-ca 1593) in his version of the Lithuanian nation's history from 1577. He saw no problem that as the Lithuanians extended into Rus', they intermarried with the locals, adopting their language, customs and faith: according to this historian, the most important criterion for being Lithuanian was one's origins. They were all the GDL's Orthodox believers, its aristocracy and nobility. Expanding on the honourable origins of the Chodkiewicz line from the Žemaitjan Boreika, back in the times of Gediminas, he summarised:

So, dear reader, yearn to know about the Chodkiewicz, About the earliest of Lithuanian patriarchs.

And consider them not as Ruthenians, according to the Greek faith. ${ }^{33}$

The descendants of Algirdas are also included in this list: the houses of Zbaraski, Wisniowiecki and Algirdaitis-Olelkaitis-Sluckis; ${ }^{34}$ and the Hlebowicz, Czartoryski and Holshany families. ${ }^{35}$

It was the Ruthenian-Lithuanians who brought the Ruthenian language to the Lithuanian nation, a people who were slightly different, though not strangers. Even though Stryjkowski gives a more comprehensive account in the second half of the 16th century, nevertheless, the 'unsanctioned' use of Ruthenian in the 15th century, compared to the sanctioned Lithuanian language used in the court of the Lithuanian grand duke at the time, gives indirect but clear confirmation of the Ruthenian language's strong position as one of the two written languages (alongside Latin), and one of the three spoken languages, of government and authority in the GDL.

The scholar's task of positioning linguistic relations in the GDL in the 15th century along the diglossia scale of prestigious-everyday is very complex. It is no less complicated in the 16th century, as in that age, the situation of the Lithuanian language became even more paradoxical. On one hand, there were increasingly more printed Lithuanian texts, and a literary language started to form; but on the other, the spheres of public use narrowed; Lithuanian was no longer used in the highest ruling or government structures. The sparse and sporadic data we have testifies to the use of Lithuanian where it was

${ }^{33}$ M. Stryjkowski, O początkach, p. 243: 'Tak tedy, czytelniku, wiedz o Chodkiewiczach, / O starożytnych z dawna litewskich dziedzicach. / A nie szacuj ich z Rusi wedlug greckiej wiary'.

${ }^{34}$ Ibid., pp. 325, 327.

${ }^{35}$ D. Kuolys, Asmuo, tauta, valstybe Lietuvos Didžiosios Kunigaikštystès istorineje literatūroje: renesansas ir barokas (Vilnius, 1992), pp. 96-97. 
needed to carry out practical administrative, judicial and religious functions orally; this included services offered by Lithuanian courtiers in the ruler's court, ${ }^{36}$ Lithuanian scribes and court officials, ${ }^{37}$ the recruited army consisting of the nobility (1535), ${ }^{38}$ and in the Magdeburgian cities of Kaunas and Vilnius. ${ }^{39}$ This data says little about which language was used when several collided in the same sphere of public life, however. ${ }^{40}$ The language diglossia, as a version of bilingualism with the existence of a strict prestigious language in Lithuanian powiats and cities of the GDL in any century has not been researched at all. Let us look at the informative example of the Magdeburgian city of Kaunas, evident from 12 city institution books from the 16th century. The same sources about the use of Lithuanian in Kaunas in the 16th century have given rise to two opposite opinions. The eminent Kaunas researcher Zigmantas Kiaupa strives to show that Lithuanian was used in public city life: 'there were many residents of Kaunas or out-of-towners who would appeal to the court of the voigt and speak Lithuanian, whereas the scribe would understand and make a record of his declaration. ${ }^{41}$ The observant researcher of historical sources Darius Antanavičius sees a different picture: the 'working' language of the Kaunas council in the mid-16th century was Polish, which superseded Lithuanian in all

${ }^{36}$ А. Дубоніс, 'Да праблемы дзяржаўнай мовы’, р. 216.

${ }^{37}$ Ibid., pp. 216-217; A.K. Antonovich researched the Ruthenian language in the Kaunas land court book in 1566-1567, and found that almost the entire text of the book was written by Lithuanian scribes. See: А.К. Антонович, 'Вопросы фонетики белорусского актового языка XVI в. По материалам судебной (актовой) книги Каунасского земского суда 1566-1567 гг.', Kalbotyra, t. 2, (1960), pp. 94-96, 101, 105, 107, 110, 112 (one of the conclusions was that the majority of the texts in the book were written by Lithuanian scribes); А.К. Антонович, Язык судебной (актовой) книги Каунасского земского суда 1566-1567 г2. Автореферат диссертачии на соискание ученой степени кандидата филологических наук (Вильнюс, 1961), р. 16.

${ }^{38}$ А. Дубоніс, ‘Да праблемы дзяржаўнай мовы’, pp. 207-208; A. Dubonis, 'Lietuvių kalba', p. 38.

${ }^{39}$ Z. Kiaupa, 'Kauno miesto vaitas ir jo aktų knygos XVI a. - XVII a. pirmojoje pusejje', Lietuvos miestu istorijos šaltiniai (Vilnius, 1988), pp. 28-29; А. Дубоніс, 'Да праблемы дзяржаўнай мовы', pp. 211, 217-218.

${ }^{40}$ In the ethnic lands, the Lithuanian language in verbal administrative matters was meant to serve as the lingua franca, see A. Dubonis, 'Lietuvių kalba', p. 38.

${ }^{41}$ Z. Kiaupa, 'Kauno vaito XVI a. vidurio knygos prabyla lietuviškai', Kultūru sankirtos. Skiriama doc. dr. Ingès Lukšaitès 60-mečiui, ed. Z. Kiaupa, et al. (Vilnius, 2000), p. 89. 
regards, and he does not believe that anyone translated declarations made in Lithuanian at the council, because all the assignees chosen by Kaunas residents to represent them were 'all Polish, and unlikely to have known how to speak Lithuanian'. ${ }^{42}$ I am more inclined to side with the first researcher than the second, as the latter, whilst having correctly noted the lack of a translator, did overlook their existence in the council's activities. One such figure was the assignee 'Pole' Maciej Nadolski, who represented Kaunas residents in their cases. An entry in the council books dated 12 May 1563 recorded that the council gave Andriejus Uršuliškis 15 days to find someone to speak in his defence, because he did not understand the Polish spoken by the plaintiff's advocate, Nadolski. Another entry declares that the advocate hired by Uršuliškis, the same Nadolski, was rehired by the plaintiff Jonas Paršelis, even though arrangements had been made to represent Uršuliškis. ${ }^{43}$ Aside from knowing written and spoken Polish and legal matters, the deserter Nadolski clearly must have known Lithuanian as well, as otherwise he would have had to prove that both his employers did not speak Lithuanian, but German or Ruthenian: the surnames of the people involved in this case indicate their Lithuanian nationality and native language. In this specific case, the particularities of language usage can be revealed. The verbal use of Lithuanian was no less prestigious than Polish, but being the only person to speak Lithuanian in a court case could prove to be financially disadvantageous, compared to knowing Polish. In addition, Polish was technically more advantageous as a written language, considered an official language in Kaunas alongside Latin. On the other hand, residents of Kaunas were not obliged to pay a fee for the services provided by this 'translator', for a language superior to their own. The re-hiring of Nadolski, and there truly were assignees like him, not only points to the demand for such services, but also indicates the domination of Lithuanian in Kaunas. ${ }^{44}$ In a

${ }^{42}$ Kauno miesto aktu knygos XVI-XVIII a. Tarybos knyga 1555-1564. Acta civilia Caunensia saec. XVI-XVIII. Liber consularis 1555-1564, ed. D. Antanavičius, Lithuanian summaries by L. Plankis (Vilnius, 2013), p. XII-XIII (the Introduction, pp. XXIX-XXX).

${ }^{43}$ Ibid., No. 1236-1237, pp. 246, 426.

${ }^{44}$ Historical Kaunas sources contain a direct translation of a record of an event from Lithuanian into Polish. On 25 November 1561, the books of the Kaunas voigt have the testimony of Ona Durstiniene in Polish about a fight that broke out at her home. This entry was made in court without an authorised intermediary, and was clearly translated from Lithuanian, as the witness announced that she did not 
discussion of the situation of the Lithuanian language in the GDL, we should always take into consideration its use in stabilising and even expanding the role of translators or language intermediaries. ${ }^{45}$

The example discussed here shows the range of problems encountered in research when we try to assess the flexible, very dynamic use of languages which changed every few decades, whose norms were set more by customs and traditions than any specific laws, and their interrelation in the GDL. It is impossible to 'imprison' language use in the 16th century in the two tables Dziarnovič proposes about diglossia relations, consisting of five horizontal and five vertical graphs. Kaunas differed from Vilnius, where Ruthenians officially made up half the city council, and where language use depended on the social-property status of burghers, nobles and officials. In the ruler's court, language use was different again. A question that remains unanswered is whether it was customary for officials holding various administrative positions in ethnic Lithuania to know Lithuanian (or at least understand it), ${ }^{46}$ as it was for Catholic priests and vicars. Ultimately, spoken language in public life was and today remains no less important, perhaps even more important, than written language.

The spoken use of the Lithuanian language was a reality of public life, yet even the scarce data discussed here unambiguously points to a distinct trend: its use declined in the first half of the 16th century, regardless of whether we consider the administrative, political, public, social or religious spheres where it was used. It was almost completely eliminated from the ruler's court, losing influential users, the nobility of Lithuanian origins, once they prioritised the Polish and Ruthenian languages (only the lords held on to the legend of their Roman origins and maintained sentiments for Lithuanian with its roots in Latin, and even tried to employ it in

understand the argument, which was in Polish. See: Kauno miesto aktu knygos XVI-XVIII a. Vaito knyga 1561-1564. Acta civilia Caunensia saec. XVI-XVIII. Liber advocatialis 1561-1564, eds. D. Antanavičius, A. Baliulis (Vilnius, 2013), No. 777.

${ }^{45}$ А. Дубоніс, ‘Да праблемы дзяржаўнай мовы’, pp. 216-217.

${ }^{46}$ The exclusive findings made by Ragauskienè allow this kind of formulation of the problem: a letter from Stanislovas Radvila, the appointed elder of Žemaitija, of September 1595 to his brother Mikalojus Kristupas ‘the Orphan' Radvila, where he writes that he has forgotten Lithuanian and will have to return to school, as, so help him God, it [Lithuanian] will prove to be necessary. See: R. Ragauskienè, Dingę istorijoje. XVI a. Lietuvos Didžiosios Kunigaikštystès bajorijos privatūs archyvai (Vilnius, 2015), p. 108 (footnote 340). 
an ideological battle with the Ruthenians, and partly with the Poles as well). ${ }^{47}$ Lithuanian written culture, itself just barely established, was far from posing any competition to Latin, Polish or Ruthenian written culture, and, as Marcelinas Ročka ${ }^{48}$ highlighted, it started to be identified with the common folk, being a lesser language compared to Latin, which was chosen as the early, true language of Lithuanians. It fell into such decline even in the land's churches that the bishops of Vilnius and Žemaitija embarked on its salvation in 1501-1503. ${ }^{49}$ The Diocese of Vilnius synod of 1526, for example, ruled that parish priests had to establish schools and teach children Lithuanian and Polish. ${ }^{50}$ Even the Grand Duke of Lithuania (and King of Poland) Sigismund II drew attention to its dire fate, with the help of the clergy. ${ }^{51}$ The same Diocese of Vilnius synod of 1526 banned conducting the baptism ritual in Lithuanian, so that any priests who could not speak Lithuanian would not violate the formula for the sacrament of baptism. ${ }^{52}$ Martynas Mažvydas, in the first sentence of the Latin Preface to his Catechism (1547), opened an even deeper wound. He alleged that some people considered the Holy Scripture to be a privilege rather strictly set aside for the clergy, not the common people, the former unjustly claiming the word of God for themselves, as if creating an individual wall or distance from God's 'other' children. In studying the Catechism,

${ }^{47}$ A. Dubonis, 'Lietuvių kalba', pp. 48-52, 56-58.

${ }^{48}$ M. Ročka, Rinktiniai raštai (Senoji Lietuvos literatūra, kn. 11), ed. M. Vaicekauskas (Vilnius, 2002), p. 123.

${ }^{49}$ A. Dubonis, 'Lietuvių kalba', pp. 50-51.

${ }^{50}$ J. Fijałek, 'Uchrześcijanienie Litwy przez Polskę', pp. 296-298. It could be that this procedure was later implemented in the Diocese of Žemaitija, as the visit report (1579) of Tarquinius Peculus mentions teachers being hired by the priests, who taught children Ruthenian, Polish, Latin and religious studies (in Ariogala, Krakès and Betygala). See: Žemaičiu vyskupijos vizitacija (1579). Visitatio dioecesis Samogitiae (A. D. 1579). Text edited, translated from Latin and index compiled by L. Jovaiša. Introduction and commentary by J. Tumelis and L. Jovaiša (Fontes ecclesiastici historiae Lithuaniae, t. 1) (Vilnius, 1998), pp. 85, 101, 121.

${ }^{51}$ Grand Duke of Lithuania (and King of Poland) Sigismund II, on 27 January 1524, having joined the Eišiškès parish to the Trakai prebendary, obliged the Eišiškes parish priest to have a preacher who could speak Lithuanian. See: Lietuvos Metrika, knyga Nr. 12 (1522-1529). Užrašymu knyga 12, eds. D. Antanavičius, A. Baliulis (Vilnius, 2001), p. 559, No. 720. Stanisław Szczekocki, the Trakai prebend and Eišiškès priest, was a Pole (?), see V. Ališauskas, T. Jaszczołt, L. Jovaiša, M. Paknys, Lietuvos kataliku dvasininkai XIV-XVI a. (Vilnius, 2009), No. 2231. Before him, the priest was the Pole Mikołaj de Poltowsko, see ibid., No. 1450.

52 J. Fijałek, 'Uchrześcijanienie Litwy przez Polskę', pp. 295-296. 
Mažvydas encouraged the common folk to be drawn in as much as possible to learn about the main truths of faith in church in their native language, ${ }^{53}$ yet he did define certain limits. In his opinion, the unenlightened, barely Christian Lithuanian people, still drowning amid pagan superstitions, could not improve in the field of religious reasoning or debate: Non loquor de abstrusioribus controuersiis religionum, de quibus promiscua multitudo ut nec iudicium praestare, ita tamen Catechesim perdiscere, eo debet, et potest. ${ }^{54}$ Lithuanian was simply unsuitable for any deeper awareness of faith. The only suitable language appropriate for an educated priest was Latin. ${ }^{55}$ Mažvydas' preface allows us to specify who the educated members of secular society were in Lithuania at the time who used Latin and Lithuanian: they were the nobility, proceres, sirs and lords. ${ }^{56}$ There was a third language used by educated Lithuanians, Polish, as Mažvydas translated a large part of his Catechism from Jan Seklucjan's (ca 1510-1578) Polish Catechism (1545). ${ }^{57}$

Mažvydas was not the only one to leave the Lithuanian language to the unprivileged estate, to the common, unenlightened Lithuanian folk. In the mid-16th century, unfavourable interpretations were made of the legend of the Lithuanians originating from Romans, the interaction of the noble Latin and the local Lithuanian languages, the transformation of Latin into the Lithuanian language, and the birth of the Lithuanian nation on the banks of the River Neris. ${ }^{58}$ Lithuanian was attributed a lower status than Latin, the true language of the Lithuanians. In the teachings of Mykolas Lietuvis, the secretary of the ruler's chancery Venclovas Mikalojaitis, presented to the young king and Grand Duke of Lithuania Sigismund Augustus,

${ }^{53}$ R. Koženiauskienè, XVI-XVIII amžiaus prakalbos ir dedikacijos (Vilnius, 1990), pp. 69-70.

${ }^{54} \mathrm{D}$. Antanavičius clarified the translation: 'I do not speak of [originally: have in mind] questions regarding the more complex matters of religion [originally: faith], on which the simple folk [originally: people] should not express their opinions [originally: have an opinion], but the Catechism is something they must and can learn', see ibid., p. 55 (original text), 70 (editor's translation).

${ }^{55}$ M. Ročka, Rinktiniai raštai, pp. 104-105, 122-123.

${ }^{56}$ Ibid., p. 105; R. Koženiauskienè, XVI-XVIII amžiaus, pp. 54-55 (proceres), 73 ('Oh, sirs, listen and reconsider'), 74 ('Oh, all you lords, have some compassion'). Terms highlighted by the article's author.

${ }^{57}$ Z. Zinkevičius, Lietuvių kalbos istorija, t. 3: Senuju raštu kalba (Vilnius, 1988), pp. 26-27.

${ }^{58}$ A. Dubonis, 'Lietuvių kalba', pp. 56-58. 
who resided in Lithuania in 1544-1548, Latin was elevated as the language of scholarship in gymnasiums, which unfortunately did not yet exist in the GDL. He added that Lithuanians, whose language was half Latin, were forced to undertake Muscovite studies, in the Russian language that was foreign to Lithuanians. ${ }^{59}$ The Vilnius palatine and secretary to the ruler, the Pole Augustinus Rotundus (Mieleski, 1520-1582), offered an even clearer discussion of the Lithuanian language's situation and purpose in linguistic relations in the GDL. In 1576, in the letter accompanying the Second Statute of Lithuania (1566) (hereafter SSL) that he himself translated into Latin, he encouraged the King and Grand Duke of Lithuania Steponas Batoras (Stephen Bathory) to replace Ruthenian with Latin, the early Lithuanian language, in state record-keeping, and even in everyday life. ${ }^{60}$ Its simpler variant, Lithuanian, was to remain where it was, with villagers and other locals, for the nobility, the descendants of Romans, in distancing themselves from their native Lithuanian, were unforgivably resorting to the barbaric Russian language. ${ }^{61}$ Rotundus was seconded by his friend Stryjkowski, who in his works told of how 500 noble Italians led by Palemon encountered rough, forest-dwelling, simple people - Lithuanians illegibly muttering ka, kur, kaip, kuo (what, where, how, etc). ${ }^{62}$ On the other hand, even before the arrival of the Romans, words from other languages constantly entered the local Lithuanians' speech, as it used to be a militant and mobile figure in early European history, from the times when Lithuanians had not yet separated from their ancestors the Goths, Getae and Gepids, and had not yet settled in these lands. ${ }^{63}$ Later, as the Italians' Latin mixed with the local Lithuanian and Žemaitjan, Palemon's descendants lost their mother tongue and adopted the local variant, whose roots lay in the crude,

${ }^{59}$ Mykolas Lietuvis, Apie totoriu, lietuviu ir maskvenu papročius (with the reprint: Michalonis Lituani De moribus tartarorum, Lituanorum et Moschorum ..., Basileae, 1615) (Vilnius, 1966), p. 49.

${ }^{60}$ Augustinas Rotundas, 'Laiškas Lenkijos karaliui ir Lietuvos didžiajam kunigaikščiui Steponui (1576)', Senoji Lietuvos literatūra, kn. 5: Šešioliktojo amžiaus raštija (Vilnius, 2000), pp. 281-283; D. Kuolys, Asmuo, pp. 66, 69.

${ }^{61}$ Augustinas Rotundas, 'Laiškas', p. 283.

${ }^{62}$ M. Stryjkowski, 'O początkach, pp. 62, 88; M. Stryjkowski, Kronika Polska, Litewska, Żmódzka i wszystkiej Rusi ... wydanie nowe będace dokładnym powtórzeniem wydania pierwotnego Królewieckiego z roku 1582 ..., t. 1 (Warszawa, 1846), pp. 55, 77.

${ }^{63}$ Ibid., p. 37. 
simple language of the original inhabitants, but with a multitude of Latin loanwords. ${ }^{64}$ This was the language of Lithuanians, confirmed in the catchcry cited by Stryjkowski Mušk, ažumušk tuos gudus (Strike and kill those Gudai) from the throes of Lithuanians' and Žemaitjans' battles against the Russian Olgovich clan in the early 13th century. ${ }^{65}$ The great Lithuanian historian Rotundus was not urging noble Lithuanians to return to their true, Latin, Lithuanian language, ${ }^{66}$ but thought it their duty, as Darius Kuolys suggests, to adopt their native language. ${ }^{67}$ Stryjkowski actually desired a re-Lithuanianisation of the entire Lithuanian nobility. Having a native language would have helped preserve a direct link with their ancestors and reinstate the nation's authority:

I wish not to list many Latin words here,

As instilling in you the Lithuanian spirit, I see, would be shameful,

You have abandoned it as your early ancestors' affair,

And are losing what they claimed with bloody swords.

How good it was when your own language was alive and well,

When the Tatar and Muscovite served under your cap. ${ }^{68}$

In the second half of the 16th century, Lithuanian was unequivocally viewed as the language of the people, the common folk and the unprivileged estate, not as a prestigious, state chancery language. Its public use was narrowing, though it had not yet been completely abandoned. ${ }^{69}$ Ruthenian was still functional (convenient), and remained one of the official chancery languages in the GDL. In the first half of the 16th century, its use in state record-keeping truly flourished. Naturally becoming well established, with existing structures where

${ }^{64}$ M. Stryjkowski, O początkach, p. 89.

${ }^{65}$ Ibid., p. 146.

${ }^{66}$ D. Kuolys, Asmuo, p. 93.

${ }^{67}$ Ibid., p. 98.

${ }^{68}$ M. Stryjkowski, O początkach, p. 89: 'Inszych tu słów tacińskich wiele nie chcę liczyć, / Bo was w swej litewczyźnie - widzę - już wstyd ćwiczyć, / Któraśsie porzucili z starych przodków sprawą, / Też tracicie, co oni szabla wzięli krwawa. / Dobrze było, gdy język u was własny płużyt, / Bo Tatarzyn, Moskwicin czapce waszej stuży.'

${ }^{69}$ It is claimed that Lithuanian had no chance of becoming a state language, as it was used as a written language only in religious matters, see G. Błaszczyk, Litwa na przełomie, p. 305. If Błaszczyk considers religion a marginal part of public life, then he is notably wrong: the religious sphere was one of the most significant spheres of public political and social life in the 15th and 16th centuries in the GDL and in Europe as a whole. 
non-Ruthenians could learn the language, Ruthenian nevertheless was never declared the only mandatory official language, restricting the population of the GDL to use other languages in public life. Nor did Ruthenian compete against Lithuanian, as the two existed in different spheres of use: Ruthenian was one of the official document and state judicial written chancery languages, whereas Lithuanian was the lingua franca of the ethnic population of Lithuania in most spheres of life. However, the emergence of a literary Lithuanian language in the early 16 th century, plus the enhancement of its lexis, shows the diverse participation of Lithuanian in the circulation of Ruthenian, Latin and Polish official written documents in the GDL, ${ }^{70}$ not to mention the appearance of official forms of chancery texts. The first Lithuanian documents in the Kingdom of Prussia date from 1578, ${ }^{71}$ and from the 1620 s in Lithuania. ${ }^{72}$

In the group of prestigious written languages, Ruthenian competed against Latin and Polish, losing out in every sense. We mentioned earlier that in the mid-15th century there was a noticeable strength-

${ }^{70}$ Research of the literary Lithuanian language of the 16th and 17th centuries by Jonas Palionis confirms its important role in public life: Ruthenian, later Polish, terminology from state chancery documents had Lithuanian equivalents or loanwords in Lithuanian literary language, meaning they were constantly adopted from the content of documents and used verbally in Lithuanian in public life and in other activities, contacts and interactions. For more, see J. Palionis, Lietuviu literatūrine kalba XVI-XVII a. (Vilnius, 1967), pp. 248 (there were relatively few Lithuanian words expressing concepts from administrative and state life, and the spheres of war and the military, law and culture), 257 (a large group of new, social, terms), 267, 271 (Slavic and Polish loanwords predominate), 296 (the literary Lithuanian language gained more benefit than harm from the influence of other languages). The existence of Lithuanian words in the Ruthenian chancery language of the GDL confirms the strong impact of the early Lithuanian language on the latter. See: K. Jablonskis, Lietuviški žodžiai senosios Lietuvos raštiniu kalboje, d. 1: Tekstai (Kaunas, 1941); K. Jablonskis, Lietuviu kultūra, pp. 272-290; Z. Zinkevičius, Iki pirmuju raštu (Lietuviu kalbos istorija, t. 2) (Vilnius, 1987), pp. 123-130.

${ }^{71}$ Order dated 6 December 1578 from the Prince of Prussia Georg Friedrich to churches in the Tilžè district and their parishioners, Prūsijos valdžios gromatos, pagraudenimai ir apsakymai lietuviams valstiečiams, comp. P. Pakarklis, ed. K. Jablonskis (Vilnius, 1960), p. 623.

${ }^{72}$ Vytautas Ališauskas revived two important facts regarding the functioning of the Lithuanian language in the chancery: two instructions in Lithuanian formulated in the office of the Žemaitijan elder Jeronimas Valavičius; one was in Lithuanian and translated into Polish, the other vice versa, see: Baltu religijos ir mitologijos reliktai Lietuvos Didžiojoje Kunigaikštystejje (XIV-XVIII a.). Šaltiniu rinkinys, ed. V. Ališauskas (Vilnius, 2016), pp. 180-181 (No. 143-144). K. Jablonskis mentioned the first instruction, in Lietuviški žodžiai, p. 309 (No. 11.11). 
ening in the use of Lithuanian, helped along by the legal sanctioning of the grand duke and the Council of Lords. Yet this was testimony to its possible decline in use in precisely the sphere where the sanctioning was meant to apply, the ruler's court. By the mid-16th century, Ruthenian started to lose its prestige. Signs of discrimination against it started to appear, noted by none other than the ruler's chancery and other high-ranking officials. Mykolas Lietuvis maintained his poor opinion of Ruthenian scribes in the mid-16th century, calling them suspicious spies of Muscovy and traitors, stealing state and royal secrets from the chancery. ${ }^{73}$ An even more painful blow for the Ruthenians came in the form of an anonymous piece of libel (1558) aimed at the Vilnius bishop, Valerijonas Protasevičius (1505-1579, Bishop of Vilnius from 1556). ${ }^{74}$ In the libel, the Ruthenian bishop is painted as a drunk whoremonger, an enemy of the altar, having together with a Polish clique seized the palace of the already withdrawn bishop, Paulius Alšeniškis (Holshany). Protasevičius started his career in the chancery of the GDL as a Ruthenian scribe, also serving Queen Bona Sforza, ${ }^{75}$ and successfully reached the Olympus of Bishop of Vilnius. Repeating Mykolas Lietuvis, and to an extent the author of the libel as well, Rotundus in his preface to the SSL in 1576 encouraged King Steponas Batoras to use the language of the Muscovite (the Grand Prince of Muscovy), an eternal and constant enemy of Lithuanians, as rarely as possible in all spheres of life, and urged him to use Lithuanian (i.e. Latin) instead. ${ }^{76}$ Ruthenian was abandoned as an official record-keeping language in the regions of the GDL. At the Vilnius Sejm of 1565-1566, the nobility of the palatinate of Podlasie asked (in January 1566) that documents from the ruler's chancery intended for them be written in Latin or Polish, as no one in Podlasie could read Ruthenian any longer. With certain exceptions, Sigismund Augustus promised to fulfil their request 'wszakoz roskaze jego kro. msc, aby tez y polskim pismem takowe rzeczy czasem s cancellaryey do was odprawowano'. ${ }^{77}$ (Mikalojus Daukša also suggested removing Ruthenian from Lithuania, but his remarks will be discussed later).

${ }^{73}$ Mykolas Lietuvis, Apie lietuviu, totoriu ir maskvenu papročius, p. 59.

${ }^{74}$ M. Ročka, Rinktiniai raštai, pp. 140-142.

75 A.I. Груша, Канщьллярыя Вялікага княства Літоўскага 40-x гадоў XVпершай паловы ХVI cm. (Мінск, 2006), рp. 141-142.

${ }^{76}$ Augustinas Rotundas, 'Laiškas', pp. 281-282.

77 Литовская Метрика. Отдель 1-2. Часть третья: Книги публичных дел, т. 1 (Русская историческая библиотека, т. 30) (Юрьев, 1914), col. 384-385. 
The chancery of the GDL appeared to be the most important stronghold of the Ruthenian language. The influential Ruthenian ruler's officials working there started to defend their language. The Palatine of Smolensk and elder of Minsk and Pinsk Vasilii Tyszkiewicz did not hide his opposition to the instruction from King and Grand Duke of Lithuania Sigimsund Augustus in 1569 that was not written in Ruthenian: he simply did not carry out the king's orders that were written in Polish. The ruler was forced to repeatedly oblige his official with the same instruction, this time written in Ruthenian. ${ }^{78}$ The task of the editors of the SSL, including Rotundus, who lauded the Latin-Lithuanian language, ${ }^{79}$ was directed at entrenching Latin in GDL law, alongside Ruthenian. The Latin version of the Statute ejected the Calvinist nobility of the GDL from the Vilnius Diet of $1565-1566 .{ }^{80}$ On the other hand, the SSL extended and legally sanctioned the mandatory use of written Ruthenian in the new state legal structure, land courts. Chapter IV.§.1 of the Statute introduced the requirement that record-keeping would take place in no other language but Ruthenian: A pisarz ziemski ma po rusku, literami $i$ stowy ruskiemi wszystkie listy i pozwy pisac, a nie inszym ięzykiem y stowy $[\ldots] .{ }^{81}$ The only other competing language in this case could only be Latin. The example of the creation of the Third Statute of Lithuania (1588) (henceforth TSL) reveals how Ruthenian almost came into a direct conflict with Polish. In the Statute, the entire order for government and rule in the GDL (the Constitution) was written in Ruthenian, including edited versions of older and newly created laws that set the norms for social relations. In the grand Preface to the TSL by the vice-chancellor Leonas Sapiega (Lew Sapieha), Ruthenian is termed our language, there is pride that the laws are

${ }^{78}$ Notice from King and Grand Duke of Lithuania Sigismund Augustus dated 10 October 1569 to Vasilii Tyszkiewicz, the Palatine of Smolensk and elder of Minsk and Pinsk, where he orders a grant of three voloks of land to Jonas Terleckas, the ruler's scribe, Lietuvos Metrika. Knyga Nr. 52 (1569-1570). Užrašymu knyga 52, eds. A. Baliulis, R. Firkovičius (Vilnius, 2004), No. 87. Grand Duke Sigismund Augustus reproaches: [...] ти с того селиа ему ещчо не поступил [...] а особливе деи вымову твоя млст чинишъ тымъ, иж есмо через лист нашъ по-полску писаныи твоеи мл росказали [...].

${ }^{79}$ Rotundus compiled a Latin version of the Statute. See: A. Zakrzewski, Wielkie Księstwo Litewskie, p. 218.

${ }^{80}$ G. Błaszczyk, Litwa na przełomie, p. 306; A. Zakrzewski, Wielkie Księstwo Litewskie, p. 257.

${ }^{81}$ Pomniki prawa Litewskiego z XVI wieku, Archiwum komisji prawniczej, t. 7, wyd. F. Piekosiński (Kraków, 1900), p. 72. 
written precisely in Ruthenian, and not in some foreign language: [...] не обчымъ якимъ языкомъ, але своимъ власнымъ [Ruthenian, meaning, our, A.D.] права списаные маемъ [...]. ${ }^{82}$ Extending the tradition of the SSL regarding the establishment of an official language for court use, the Third Statute was amended to contain the instruction (IV.§.37) that only nobles competent in matters of law and Ruthenian writing could be appointed as castle court scribes. ${ }^{83}$ The pro-active promotion of Ruthenian in both statutes can be largely viewed as the goal of making its use legally established in the GDL, thus affording it the status of a mandatory official (state) language. This also happens to be the dominant assessment of this question in scholarly literature. It is not difficult to identify Polish, the competitor of Ruthenian, as according to the confirmation privilege of King Sigismund Vasa, the TSL was meant to be printed in Polish and Ruthenian, ${ }^{84}$ yet only the Ruthenian version was published in 1588. Leonas Sapiega wanted to see a Polish printed version of the Statute. In his letter to Kristupas Radvila Perkūnas in 1588, he explained the difficulties of translating from Ruthenian to Polish, despite denying this reason a couple of decades later. It is thought that Sapiega was opposed to the use of Polish in law, and defended Ruthenian as one of the features of the GDL's independence. ${ }^{85}$ The circumstances by which the influential compilers of two legal codes had to resort to legal norms in order to ensure Ruthenian held on to its official (state) language status actually already testified to its decline as an official written language. ${ }^{86}$ Ruthenian could not withstand the pressure of Polish and Latin in the diglossia situation, and gradually ended up in a less than prestigious, lower position. By the 17th century, Ruthenians themselves, even the clergy, ceased using it in communication. ${ }^{87}$

82 J. Lappo, 1588 metu Lietuvos Statutas, t. 2. Tekstas (Kaunas, 1938), p. 17.

${ }^{83}$ Ibid., p. 211.

${ }^{84}$ Ibid., pp. 5-9; A. Zakrzewski, Wielkie Księstwo Litewskie, p. 223.

${ }^{85}$ Ibid., p. 224.

${ }^{86}$ M. Мозер, 'Что такое', p. 231. The author cites B. Strumiński, 'The Language Question in the Ukrainian Lands before the Nineteenth Century', Aspects of the Slavic Language Question, vol. 2: East Slavic, eds. H. Goldblatt, R. Picchio (New Haven, 1984), p. 22.

${ }^{87}$ M. Мозер, 'Что такое', pp. 254-255. The author shows that the main Ruthenian feature of written text among users was simply using the Cyrillic alphabet, see ibid., pp. 253-254. 
Once the use of Ruthenian went into permanent decline, Lithuanian experienced a noticeable revival in the late 16th century. This was linked not just to reforms in the Catholic Church, the Counter Reformation, the activities of the Jesuits in Lithuania, and the emergence of Lithuanian religious texts, i.e. the broader Lithuanianisation of religious matters. After the court reforms of 1564-1565, when estate-based land courts for the nobility and an appeals court, the Tribunal, were created, and through the powiat nobility's participation in the diets of the Polish-Lithuanian Commonwealth, etc, the lower levels of the Lithuanian nobility started to become more actively involved in social-political life. In the famous Postilla (1599) prefaces addressed to the Medininkai (Žemaitjan) bishop Merkelis Giedraitis and interested readers, Mikalojus Daukša (1527/38-1613) expressed his joy over the improved situation of the Lithuanian language: he thanked the Almighty Bishop, for administering the vacated Diocese of Vilnius, for addressing the shortage of priests and preachers who could speak Lithuanian, and for saving the native Lithuanian language from its quagmire and death. ${ }^{88}$ Daukša envisaged a bright future for it, providing that the nobility, following the Saviour, remained aware of their native language: they had to fervently ensure its wider use, since by learning and using Polish they had inadmissably spurned their own language, abandoning and practically renouncing their own mother tongue. He believed that apart from the higher nobles (magnates) z przednejszych, the majority did not actually know Polish or had only a very poor understanding of the language. ${ }^{89}$ Daukša went on to list the mandatory spheres where Lithuanian had to be used: in the broader sense, in the creation of legislation, recording history and publishing, ${ }^{90}$ state government affairs, at Church and in the home; and more narrowly, to ensure that readers would benefit from Postilla and would treasure, use and nurture their native language. ${ }^{91}$ Therefore, the language of use had to be enriched, improved and embellished. In parallel, he did support the use of Polish in the GDL, which had become almost like a native language once

${ }^{88}$ R. Koženiauskienè, XVI-XVIII amžiaus, pp. 143-144 (M. Giedraitis was the priest of the vacated Diocese of Vilnius).

${ }^{89}$ Ibid., p. 145.

${ }^{90}$ Perhaps he is suggesting Lithuanians have Maciej Stryjkowski's Kronika Polska ... (1582) translated from Polish when he talks about a published history tome in the native language.

${ }^{91}$ R. Koženiauskienè, XVI-XVIII amžiaus, pp. 146-147. 
everyone had joined into one state. ${ }^{92}$ Whereas he was not opposed to the existence of Polish, he was of quite a different opinion when it came to Ruthenian. Daukša urged the use of Lithuanian in the creation of state legislation wszyscy ustawy, thereby seeking to lessen the role of Ruthenian, as at that time there were no laws of the GDL that were in Polish. This was a clear allusion to the TSL, published in 1588, evident in his remark in the Preface, identical to the one already cited here from Leonas Sapiega's Preface: не обчымъ якимъ языкомъ, але своимъ власнымъ права списаные маемъ $^{93}$ (Sapieha), while Daukša translated Postilla into our Lithuanian language $w$ wtasny ięzyk nasz Litewski przełożyt. ${ }^{94}$ On the other hand, certain contradictions can be seen in the optimism of Daukša, a canon from the Diocese of Žemaitija. His joy over the nobility's use of Lithuanian is immediately soured by his thoughts on how they had basically renounced it, their native language. A few decades earlier, Stryjkowski, another canon of the diocese, had voiced similar ideas. We have already noted his lenience towards the Russified magnates and lords of Lithuanian origin who had rejected their native language, whereas he wanted to see the lower layers of the Lithuanian nobility preserving their native tongue. ${ }^{95} \mathrm{He}$ was not pleased that Lithuanians who had settled in Rus' had allowed themselves to become Russified. His opinion is revealed in the narrative about Erdvilas, the Prince of Novahrudok, who distributed lands in conquered areas of Rus' to Žemaitjan and Lithuanian knights in the early 13th century. The new settlers formed relationships with Christian (Orthodox) Ruthenians: they could be found in just about every corner of Rus', but hardly any of them understood Lithuanian. ${ }^{96}$ In the already cited verses about the denationalisation of the Lithuanian nobility, 'How good it was when your own language was alive and well, when the Tatar and Muscovite served under your cap', ${ }^{97}$ he neglects to mention in favour of which language the native tongue was abandoned: perhaps Ruthenian, but in actual

92 Ibid., p. 147.

${ }^{93}$ See footnote 82 .

${ }^{94}$ R. Koženiauskienè, XVI-XVIII amžiaus, p. 136.

${ }^{95}$ D. Kuolys, Asmuo, p. 88, 95-97. Unlike Rotundus, he does not urge a return to using the native Latin language. See ibid., pp. 66-69. Cf. footnotes 66-67.

${ }^{96}$ M. Stryjkowski, Kronika Polska, Litewska, t. 1, p. 236.

${ }^{97}$ See footnote 68 . 
fact it was Polish. ${ }^{98}$ The preface from the Polish and Lithuanian Catechism (1598) compiled by the Evangelical Merkelis Petkevičius (1550-1608) helps us make sense of these contradictory opinions. Here, we learn more about the relations between the dominant languages in ethnic Lithuania. Petkevičius' opinion is all the more important as he was a state official, a scribe with the Vilnius land court and the Tribunal, who used the 'state' Ruthenian language in his work. In his preface, he speaks only about the Lithuanian and Polish bilingualism of the nobility, i.e. of the lords, masters and patrons (gospodarzy, patronowie). Polish had become so widespread that most lords and patrons no longer knew Lithuanian, and would hire Polish Evangelical priests. The latter, regardless of the depth of their piety, were incapable of teaching the common folk about God's will. ${ }^{99}$ Nevertheless, the Lithuanian Protestants still had numerous educated bilingual members in their midst (na litewski ięzyk część niemała przełożywszy oboyga ięzyka umieiętnym). ${ }^{100}$ Comparing the information from Daukša and Petkevičius from the same period, we are left to believe that both saw a similar linguistic situation in the Lithuanian powiats of the GDL, only their descriptions were somewhat different: 1) the aristocracy, the higher nobles (z przednejszych, gospodarzy, patronowie) usually no longer knew Lithuanian, but had excellent knowledge of and used Polish; 2) the remainder of the nobility could still speak Lithuanian well, Polish less so, yet they could not resist the rapid spread of the Polish language and were becoming bilingual; 3) as Lithuanian-Polish bilingualism developed, the educated Lithuanian noble at the end of the 16th century still found it easier to understand Lithuanian rather than Polish writing, otherwise the Lithuanian part of Petkevičius' text would not have been necessary; 4) Ruthenian was not used among the Lithuanians.

Language use in the second half of the 16th century in the GDL does not fall easily into the relative categories of prestigious-not

${ }^{98}$ Here, like Daukša regarding the use of Polish in Lithuania, Stryjkowski avoids a stricter assessment of how widespread the use of Polish actually was, and this was no accident, as he does analyse linguistic relations quite closely in his works. The reason must lie in his pride in Poland, an irrevocable example of the flourishing freedoms and rights of the boyar estate, a land of perfect order. See D. Kuolys, Asmuo, pp. 100-101.

${ }^{99}$ R. Koženiauskienè, $X V I-X V I$ amžiaus, p. 155; for the original text, see pp. $150-152$.

${ }^{100}$ Ibid., p. 152. 
prestigious, or high-low. The functions of Ruthenian in state record-keeping rapidly retracted from the middle of the 16th century, and the scale of its spoken use in public life was not very clear either. Lithuanian earned more prestige in the stronger Catholic Church structures. As had been the case for Ruthenians in the ruler's chancery, now the Catholic Church became a bastion for the use of their native tongue for Lithuanians. The revival of Lithuanian in all spheres of life in the country had to originate from this institution; in record-keeping it would have had to replace Ruthenian, Latin and even Polish. In his preface to Postilla in 1599, resting on the shoulders of Merkelis Giedraitis, the actual pastoral head of the Lithuanian Catholic Church, Daukša announced the modern ethnic Lithuanian nation's political-cultural guidelines for the Lithuanian lands of the GDL. The most important task here was the use and improvement of the native language. The problem of the reduced use of the Ruthenian language in the GDL did not give rise to a similar political agenda, as the Ruthenians of the GDL did not constitute a nation. In the 15 th century, when works of fiction emerged alongside Ruthenian chancery writing, the language was still not associated with literary writing in general, and no efforts were made to develop its communicative functions until the 16th century. ${ }^{101}$ Later, Ruthenian facilitated a better understanding of the Holy Scriptures, as during the 16th century Ruthenians had an ever poorer understanding of Church Slavonic. ${ }^{102}$

$* * *$

There is no evidence of the status of Ruthenian as a state language, despite this concept being so popular in Belarusian historiography. Its use as one of several official record-keeping languages in the Lithuanian lands of the GDL is a testimony to its practical importance, knowing and learning at certain layers of the population, social, ethnic and professional, but it says nothing definitive about the lower status of Lithuanian compared to Ruthenian.

According to modern socio-linguistic methods, there is no evidence for the prestigious use of Ruthenian in public life. In polylingual situations in the GDL, its status comes across as complex. Regardless of the socio-cultural group of users (ruler, administration, estates), nations and ethnoses, territory, judicial body (the ruler's domain, the nobility's domains, Magdeburgian cities, confessions), the 'length' of

${ }^{101}$ М. Мозер, 'Что такое', р. 231.

102 Ibid., p. 252. 
time, the means of language use, whether it be written or spoken, all of this created a different hierarchy of language use on each separate occasion. In the middle of the 15th century, the Lithuanian nobility raised its language to prestigious heights, positioning it on an equal footing with Polish. The official chancery languages, Latin and Ruthenian, were not sanctioned as prestigious. Three languages served the public spoken sphere in the GDL: Polish, Lithuanian and Ruthenian. In the first half of the 16th century, language use underwent noticeable changes. Ruthenian gained a stronghold not just in official record-keeping, the legislature, etc, but also became one of the languages that was widely used by high-ranking officials in the ruler's court and bodies of state governance. The spheres where Lithuanian was used narrowed down, as it was attributed to the unprivileged estate: peasants and the weaker class of burghers from minor Magdeburgian cities. On the other hand, Lithuanian did not experience discrimination: the highest government organs, lords of Lithuanian origins, and the Catholic Church saw to its preservation and defence. Competing against the ever-stronger Polish language in the GDL, by the mid-16th century Ruthenian had started to be pushed out of use. Influential officials and intellectuals discriminated against it, in the form of ideas and specific treatises. Regions of the GDL (Podlasie) ceased to use it. Its official replacement was to be Lithuanian, i.e. Latin, as the early Lithuanian language, not Polish. This 'Latinisation' helped keep the question of the Lithuanian language's role alive in public life throughout the whole 16th century. This was one of the circumstances that helped revive the use of the language, while the land's modernisation in the late 16th century allowed Lithuanian intellectuals to create the political-cultural guidelines for the ethnically renewed Lithuanian nation in the Lithuanian lands of the GDL, exhibiting the co-existence of two prestigious languages, Lithuanian and Polish.

\section{Author Details}

Artūras Dubonis is a senior research fellow. He graduated from Vilnius University in 1987, completing his $\mathrm{PhD}$ in 1996. He has worked at the Lithuanian Institute of History since 1988, where he is the head of the Archaeography Department and an academic programme supervisor. His scholarly interests are Lithuanian society and sources about its history from the 13th to the 16th centuries, and the Lithuanian Metrica and other historical sources.

Address: Lithuanian Institute of History, Kražių g. 5, LT-01108, Vilnius

E-mail: arturas.dubonis@istorija.lt 


\section{References}

Akta unji Polski z Litwa 1385-1791, wyd. S. Kutrzeba i W. Semkowicz (Kraków, 1932).

ALIŠAUSKAS, V., JASZCZOŁT, T., JOVAIŠA, L., PAKNYS, M. Lietuvos kataliku dvasininkai XIV-XVI a. (Vilnius, 2009).

Archiwum komisji prawniczej, t. 7, wyd. F. Piekosiński (Kraków, 1900).

Baltu religijos ir mitologijos reliktai Lietuvos Didžiojoje Kunigaikštystèje (XIV-XVIII a.). Šaltiniu rinkinys, comp. V. Ališauskas (Vilnius, 2016).

BŁASZCZYK, G. Litwa na przełomie średniowiecza i nowożytności 1492-1569 (Poznań, 2002).

DUBONIS, A. 'Lietuviu kalba Lietuvos Didžiojoje Kunigaikštystejje XIV a. pabaigoje ir iki pirmosios knygos $(1547 \mathrm{~m}$.): vartojimo politika ar politinis vartojimas?', Lietuvos Didžiosios Kunigaikštystès istorijos kraštovaizdis. Moksliniu straipsniu rinkinys, skiriamas profesorès Jüratès Kiaupienès 65-čiui, comp. R. Šmigelskytè-Stukienè (Vilnius, 2012).

DZIARNOVIČ, A. 'In Search of Homeland: „Litva/Lithuania“ and „Rus'/Ruthenia“" in the Contemporary Belarusian Historiography', Belarusian Political Science Review. International Journal of Political Studies, vol. 3: 2014-2015 (Kaunas, 2015).

FIJAŁEK, J. 'Uchrześcijanienie Litwy przez Polskę i zachowanie w niej języka ludu', Polska i Litwa w dziejowym stosunku (Warszawa etc., 1914).

Hansisches Urkundenbuch, Bd. 11, ed. v. W. Stein (München u. Leipzig, 1916).

Ioannis Dlugosii Annales seu Cronicae incliti Regni Poloniae, lib. 10 (1370-1405) (Varsaviae, 1985).

Ioannis Dlugosii Annales seu Cronicae incliti Regni Poloniae, lib. 11 (1413-1430) (Varsaviae, 2000).

Ioannis Dlugosii Annales seu Cronicae incliti Regni Poloniae, lib. 11 et 12 (1431-1444) (Varsaviae, 2001).

JABLONSKIS, K. Lietuviški žodžiai senosios Lietuvos raštiniu kalboje, d. 1: Tekstai (Kaunas, 1941).

JABLONSKIS, K. Lietuviu kultūra ir jos veikëjai, comp. V. Merkys (Vilnius, 1973).

KARALIUS, L. 'Lietuvos Metrikos tyrimams skirtas baltarusiu periodinis leidinys', Lietuvos Metrikos naujienos, nr. 5-02001 (Vilnius, 2002).

Kauno miesto aktu knygos XVI-XVIII a. Tarybos knyga 1555-1564. Acta civilia Caunensia saec. XVI-XVIII. Liber consularis 1555-1564, ed. D. Antanavičius, Lithuanian summary ed. L. Plankis (Vilnius, 2013).

Kauno miesto aktu knygos XVI-XVIII a. Vaito knyga 1561-1564. Acta civilia Caunensia saec. XVI-XVIII. Liber advocatialis 1561-1564, eds. D. Antanavičius, A. Baliulis (Vilnius, 2013).

KIAUPA, Z. 'Kauno miesto vaitas ir jo aktų knygos XVI a. - XVII a. pirmojoje pusèje', Lietuvos miestu istorijos šaltiniai (Vilnius, 1988). 
KIAUPA, Z. 'Kauno vaito XVI a. vidurio knygos prabyla lietuviškai', Kultūru sankirtos. Skiriama doc. dr. Ingès Lukšaitès 60-mečiui, comp. Z. Kiaupa, et al. (Vilnius, 2000).

KOŽENIAUSKIENĖ, R. XVI-XVIII amžiaus prakalbos ir dedikacijos (Vilnius, 1990).

KUOLYS, D. Asmuo, tauta, valstybè Lietuvos Didžiosios Kunigaikštystès istorinèje literatūroje: renesansas ir barokas (Vilnius, 1992).

LAPPO, J. 1588 metu Lietuvos Statutas, t. 2, Tekstas (Kaunas, 1938).

LAZUTKA, S. 'Język Statutów litewskich i Metryki litewskiej', Lithuania, Nr. 1-2 (1997).

Lietuvos didžiojo kunigaikščio Aleksandro Jogailaičio dvaro sąskaitu knygos (1494-1504), comp. D. Antanavičius, R. Petrauskas (Vilnius, 2007).

Lietuvos Metrika (1528-1547). 6-oji Teismu bylu knyga, comp. S. Lazutka, I. Valikonytè, et al. (Vilnius, 1995).

Lietuvos Metrika. knyga Nr. 12 (1522-1529). Užrašymu knyga 12, comp. D. Antanavičius, A. Baliulis (Vilnius, 2001).

Lietuvos Metrika. Knyga Nr. 52 (1569-1570). Užrašymu knyga 52, comp. A. Baliulis, R. Firkovičius (Vilnius, 2004).

MATUSAS, J. 'Nuo kada Lietuvoje kalbama lietuviškai', Mūsu Vilnius. nr. 16(210) (1936).

Mykolas Lietuvis, Apie totoriu, lietuviu ir maskvenu papročius (with the reprint Michalonis Lituani De moribus tartarorum, Lituanorum et Moschorum ..., Basileae, 1615) (Vilnius, 1966).

PALIONIS, J. Lietuviu literatūrine kalba XVI-XVII a. (Vilnius, 1967).

PIETKIWICZ, K. Dwór litewski wielkiego księcia Aleksandra Jagiellończyka (1492-1506), Lietuvos valstybe் XII-XVIII a., sud. Z. Kiaupa, A. Mickevičius, J. Sarcevičienė (Vilnius, 1997).

PIETKIWICZ, K. Wielkie Księstwo Litewskie pod rządami Aleksandra Jagiellończyka (Poznań, 1995).

Prūsijos valdžios gromatos, pagraudenimai ir apsakymai lietuviams valstiečiams, comp. P. Pakarklis, ed. K. Jablonskis (Vilnius, 1960).

RAGAUSKIENE, R. Dinge istorijoje. XVI a. Lietuvos Didžiosios Kunigaikštystès bajorijos privatūs archyvai (Vilnius, 2015)

RAGAUSKIENĖ, R. 'Kalbinè padètis Lietuvos Didžiojoje Kunigaikštystejje (iki XVI a. vid.): interpretacijos istoriografijoje', Lituanistica, nr. 3(93) (2013).

Regesta historico-diplomatica Ordinis S. Mariae Theutonicorum 1198 1525, pars 1: Regesten zur Ordensbriefarchiv, vol. 1: 1198-1454, Zweiter Halbband (1433-1454), Hrsg. E. Joachim, W. Hubatsch (Göttingen, 1948).

ROČKA, M. Rinktiniai raštai (Senoji Lietuvos literatūra, kn. 11), comp. and ed. M. Vaicekauskas (Vilnius, 2002).

Senoji Lietuvos literatūra, kn. 5: Šešioliktojo amžiaus raštija (Vilnius, 2000).

SKIBNIEWSKA, J. Dwór królewski Aleksandra Jagiellończyka w latach 1501-1506 (Lublin, 2015). 
STRUMIŃSKI, B. 'The Language Question in the Ukrainian Lands before the Nineteenth Century', Aspects of the Slavic Language Question, vol. 2: East Slavic, H. Goldblatt, R. Picchio (eds.) (New Haven, 1984).

STRYJKOWSKI, M. Kronika Polska, Litewska, Żmódzka i wszystkiej Rusi ... wydanie nowe będace dokładnym powtórzeniem wydania pierwotnego Królewieckiego z roku 1582 ..., t. 1, (Warszawa, 1846).

STRYJKOWSKI, M. O początkach, wywodach, dzielnościach, sprawach rycerskich i domowych sławnego narodu litewskiego, żemojdzkiego i ruskiego ..., opracowała J. Radziszewska (Warszawa, 1978).

SZWEDA, A. Organizacja i technika dyplomacji polskiej w stosunkach z Zakonem Krzyżackim w Prusach w latach 1386-1454 (Toruń, 2009).

Vetera monumenta Poloniae et Lithuaniae gentiumque finitimarum historiam illustrantia, ... ab A. Theiner, t. 2 (1410-1572) (Roma, 1861).

VLADIMIROVAS, L. 'Kokia kalba buvo kalbama ir rašoma Lietuvos Didžiojoje Kunigaikštystėje XIV-XVII amžiais?', Lietuvos TSR aukštujų mokyklu mokslo darbai. Istorija, t. 22 (1982).

ZAKRZEWSKI, A. Wielkie Księstwo Litewskie (XVI-XVIII w.). PrawoUstrój - Społeczeństwo, (Warszawa, 2013).

Žemaičiu vyskupijos vizitacija (1579). Visitatio dioecesis Samogitiae (A. D. 1579). Ed. trans. from Latin and index by L. Jovaiša. Intro. and explanations by J. Tumelis, L. Jovaiša (Fontes ecclesiastici historiae Lithuaniae, t. 1) (Vilnius, 1998).

ZINKEVIČIUS, Z. Iki pirmuju raštu (Lietuvių kalbos istorija, t. 2) (Vilnius, 1987).

ZINKEVIČIUS, Z. Senujų raštų kalba (Lietuviu kalbos istorija, t. 3) (Vilnius, 1988).

АНТОНОВИЧ, А. К. 'Вопросы фонетики белорусского актового языка XVI в. По материалам судебной (актовой) книги Каунасского земского суда 1566-1567 гг.', in Kalbotyra, t. 2 (1960).

АНТОНОВИЧ, А. К. Язык судебной (актовой) книги Каунасского земского суда 1566-1567 г2. Автореферат диссертации на соискание ученой степени кандидата филологических наук (Вильнюс, 1961).

Вялікае Княства Літоўскае. Энщыклапедыя у двух тамах, т. 1: A-К, рэдкал.: Г. П. Пашкоў (гл. рэд.) і інш. (Мінск, 2005).

Гісторыя Беларусі, т. 2: аўтары: Ю. Бохан, Г. Галенчанка і інш. Беларусь у перьяд Вялікага Княства Літоўскага (Мінск, 2008).

ГРУША, А. І. Канцььлярыя Вялікага княства Літоўскага 40-х гадоў XV- першай паловы XVI cm. (Мінск, 2006).

ДЗЯРНОВІЧ, А. 'Літоўская мова ў Вялікім Княстве Літоўскім: паміж функцыяй і статусам’, Палітычная сфера, № 16-17 (1-2) (2011).

ДЗЯРНОВИЧ, О. 'Литовский язык в мультикультурном обществе Великого княжества Литовского XV-XVII веков’, Исторический путь литовской письменности. Сборник материалов конференции, науч. ред. С.Ю. Темчин (Вильнюс, 2005). 
ДУБОНІС, А., ‘Да праблемы дзяржаўнай мовы ў Вялікім Княстве Літоўскім’, Metriciana. Даследаванні і матэрыялы Метрыкі Вялікага Княства Літоўскага, т. 3 (Мінск, 2004).

ЖУРАВСКИЙ, А. 'О канцелярском языке Великого Княжества Литовского', Lietuvos istorijos metraštis. 1983 metai (Vilnius, 1984).

ЛАЗУТКА, С.; ВАЛИКОНИТЕ, И.; ГУДАВИЧЮС, Э. Первый Литовский Статут (1529 г.) (Vilnius, 2004).

Литовская Метрика. Отдельы 1-2. Часть третья: Книги публичных дел, т. 1 (Русская историческая библиотека, т. 30) (Юрьев, 1914).

МОЗЕР, М. 'Что такое „простая мова“?', Studia Slavica Academiae Scientiarum Hungaricae, t. 47(3-4), (2002).

МОЙСІЄНКО, В. 'До проблеми виділення „західноруського“ наріччя, або якою мовою писали на теренах українсько-білоруського пограниччя у столітті', Украӥнські гуманітарний огляд, вип. 7 (Київ, 2002).

СВЯжЫНСКІ, У. 'Аб статусе беларускай і ўкраінскай моў у часы Вялікага Княства Літоўскага', Metriciana. Даследаванні і матэрыялы Метрыкі Вялікага Княства Літоўскага, т. 2 (Мінск, 2003).

СВЯЖЫНСКІ, У. 'Вяртаючыся да дыскусіі пра афіцыйную мову Вялікага Княства Літоўскага', Metriciana. Даследаванні і матэрыялы Метрыкі Вялікага Княства Літоўскага, т. 3 (Мінск, 2004).

СВЯжЫНСКІ, У. 'Праблема ідэтыфікацыі афіцыйнай мовы Вялікага Княства Літоўскага', Metriciana. Даследаванні і матэрыяль Метрыкі Вялікага Княства Літоусскага, т. 1 (Мінск, 2001). 


\section{LIETUVOS DIDŽIOSIOS KUNIGAIKŠTYSTÉS OFICIALIOS \\ („VALSTYBINĖS“) KALBOS PRESTIŽAS IR NUOSMUKIS (XV-XVI A.): BALTARUSIŲ ISTORIOGRAFIJOS PROBLEMOS}

Santrauka

\section{ARTUTRAS DUBONIS}

Straipsnyje rusėnų (,senosios baltarusių“) kalbos vartojimas nagrinėjamas kaip Lietuvos Didžiosios Kunigaikštystès oficialios (,valstybinès“) kalbos problema, pateikiama naujausiuose Baltarusijos ir Lenkijos tyrèjų lituanistų darbuose. Baltarusių istoriografijoje pamėgti rusėnų kalbos valstybinio statuso argumentai atmetami. Moderniomis sociolingvistinėmis metodikomis baltarusių tyrejjų aprašomas prestižinis rusėnų kalbos statusas viešajame gyvenime neįrodomas. Nelygu socialinè-kultūrinè vartotojų grupè (valdovas, administracija, luomai), tautos ir etnosai, teritorija, juridinis vienetas (valdovo domenas, bajorijos domenai, magdeburginiai miestai, konfesijos), „ilgasis“ laikas, kalbos vartojimo forma (sakytinė ar rašytinė) - visa tai kaskart kūrè kitokią kalbų vartojimo hierarchiją.

XV a. Lietuvos Didžiosios Kunigaikštystès viešajame gyvenime vartotos keturios kalbos: žodžiu - lenkų, lietuvių ir rusėnų, raštu - rusẻnų ir lotynų. XVI a. pirmoje puseje kalbų vartojimas pastebimai kito. Rusėnų kalba igijo stiprias pozicijas krašto administracijoje ir kultūriniame gyvenime. Lietuvių kalbos vartojimo sritys siaurejo, ji buvo priskirta neprivilegijuotam valstybės luomui. Kita vertus, lietuvių kalba nepatyre diskriminacijos, kaip konkuruojant su ịsigalinčia lenkų kalba nutiko rusėnų kalbai, nuo XVI a. vidurio stumiamai iš viešojo vartojimo. Tačiau oficialiai pakeisti rusėnų kalbą Lietuvos Didžiojoje Kunigaikštystejje mėginama ne lenkų, bet „lietuvių“, t. y. lotynų kalba, kuri buvo suvokiama kaip senoji lietuvių kalba. Šis „lotynizavimas“ padejjo išsaugoti lietuvių kalbos vaidmens klausimą viešajame gyvenime visą XVI a. Dèl šios priežasties kalbos vartojimas atsigavo, o krašto modernejjimas XVI a. pabaigoje leido lietuvių intelektualams kurti etniškai atnaujintos lietuvių tautos politinès-kultūrinès programos gaires lietuviškoms LDK žemėms su dviejų prestižinių kalbų - lietuvių ir lenkų - koegzistencija 